\title{
ORGANIC AMENDMENT ON SOIL QUALITY AND YIELD PERFORMANCE OF DRY DIRECT SEEDED BORO RICE
}

\author{
M.M. Rahman ${ }^{1}$ and M. Uddin ${ }^{2}$ \\ ${ }^{1}$ Professor and ${ }^{2}$ Post-graduate student, Department of Agronomy, Bangladesh Agricultural University, Mymensingh \\ Corresponding Email: rahmanag63@gmail.com
}

(Received: 10 October, 2020, Accepted: 03 November, 2020)

Keywords: Trichocompost, vermicompost, mustard oil cake, water saving, boro rice, organic matter

\begin{abstract}
An experiment was conducted at Khitrokashipur, Durgapur, Rajshahi during March to June 2018 to study the effect of organic amendment on soil quality and yield performance of dry direct seeded boro rice var. BRRI dhan28. The treatments were Trichocompost (TC), Vermicompost (VC), mustard oil cake (MOC), Trichocompost + mustard oil cake (TC+MOC), Vermicompost + mustard oil cake (VC + MOC), and no amendment control. The experiment was laid out in a randomized complete block design with three replications. Trichocompost and Vermicompost were applied @ $3 \mathrm{t} \mathrm{ha}^{-1}$, while mustard oil cake was used @ $0.5 \mathrm{t} \mathrm{ha}^{-1}$. The results revealed that Trichocompost and vermicompost fertilization exerted significant influence on yield performance of BRRI dhan 28 in boro season. The treatment trichocompost $\left(\mathrm{T}_{1}\right) @ 5 \mathrm{t} \mathrm{ha}^{-1}$ produced the highest grain yield $\left(5.95 \mathrm{t} \mathrm{ha}^{-1}\right)$, while the mustard oil cake $\left(\mathrm{T}_{3}\right) @ 0.5 \mathrm{t} \mathrm{ha}^{-1}$ the highest effective tillers hill ${ }^{-1}(15.33)$, though the highest straw yield $\left(5.46 \mathrm{t} \mathrm{ha}^{-1}\right)$ was produced in the treatment $\mathrm{VC}+\mathrm{MOC}\left(\mathrm{T}_{5}\right)$. In case of soil properties, Trichocompost $\left(\mathrm{T}_{1}\right) @ 3 \mathrm{t} \mathrm{ha}^{-1}$ and mustard oil cake $\left(\mathrm{T}_{3}\right) @ 0.5 \mathrm{t} \mathrm{ha}^{-1}$ improved soil organic matter content, while Trichocompost $\left(\mathrm{T}_{1}\right) @ 3 \mathrm{tha}^{-1}$ and Vermicompost $\left(\mathrm{T}_{2}\right) @ 0.5 \mathrm{tha}^{-1}$ improved phosphorus and potassium content. Field capacity was greatly influenced by Trichocompost $\left(\mathrm{T}_{1}\right) @ 3$ t ha ${ }^{-1}$ and Vermicompost + mustard oil cake $\left(\mathrm{T}_{5}\right)$. Soils with Trichocompost $\left(\mathrm{T}_{1}\right) @ 3$ tha $^{-1}$ showed the highest bulk density. It was concluded that organic amendment greatly improved the yield performance of BRRI dhan 28 and also soil physical and chemical properties under dry direct seeded boro rice cultivation system.
\end{abstract}

\section{Introduction}

Rice (Oryza sativa L.) contributes $95 \%$ to food production in Bangladesh. About $77 \%$ of cropped area of Bangladesh is used for rice production, with the annual production of 37.36 million tons from 11.68 million ha of land (AIS, 2020). The rice production in the country has been increased by 3.4 folds over the last four decades. In Bangladesh, more than 55.0 million tons of rice will be required by the year 2050 when population of Bangladesh will be 233.3 million (Basak, 2009). The possibility of expanding the area under rice in near future is limited. The major challenges to achieve this gain are accompanied with less water, labor shortage, and negative impact of chemicals use, especially for attaining long-term sustainability.

The rice production with less water and labor can be achieved by adopting different climate smart technologies, such as dry direct seeding, organic amendment and cropping pattern renovation. Direct seeding of rice refers to the process of establishing the rice crop from seeds directly sown in the field rather than by transplanting of seedlings from the nursery. There are three principal methods of direct seeding of rice (DSR): dry seeding (sowing dry seeds into dry soil), wet seeding (sowing pregerminated seeds on wet puddle soils) and water seeding (seeds sown into standing water). Dry seeding 
has been the principal method of rice establishment since the 1950s in developing countries (Pandey and Velasco, 2005). In the traditional transplanting system (TPR), puddling creates a hard pan below the plough-zone and reduces soil permeability. It leads to high losses of water through puddling, surface evaporation and percolation.

Water resources, both surface and underground are shrinking and water has become a limiting factor in rice production (Rahman, 2019). In practice, boro rice uses about $70 \%$ of total water used in agriculture. Therefore, technologies and practices need to be in place for sustaining boro rice production, while increasing cropping intensity with minimal water input especially in the drought prone areas. Dry seeding allows cultivation of boro rice with less than 50\% irrigation water compared with that required in puddle transplanted method (Rahman et al., 2012: Rahman and Masood, 2014, Rahman, 2019). The adoption of a direct-seeded method for lowland rice culture would significantly decreases costs of rice production (Rahman and Masood, 2014). As this cultivation system is done in dry land, organic matter decreases rapidly and therefore, it needs to increase organic matter status in soil. Direct seeding is done after dry cultivation, and controlled irrigation is provided to keep the soil at field capacity. However, standing water is maintained for a very short period of time from panicle initiation to heading or grain filling (Rahman et al., 2020). Organic amendment through Trichocompost, Vermicompost and mustard oil cake increases organic matter content and water holding capacity of soil as well as allows more infiltration to increase water retention capacity of the soil (Minasny and Mcbratney, 2018).

T. aman - Mustard - DDS boro rice is considered as one of the most promising cropping patterns for increasing farm productivity and farmers income (Rahman, 2018). However, it is important to adopt management practices that improve the system productivity and soil health as well. Therefore, the present study was undertaken to evaluate the effect of organic amendment on soil quality and yield performance of dry seeded boro rice under T. aman rice - Mustard - DDS boro rice cropping pattern.

\section{Materials and Methods}

\section{Site and soil}

The experiment was conducted at farmers' field in Khitrokashipur village of Durgapur upazilla in Rajshahi district. The field is located at $24^{\circ} 75^{\prime} \mathrm{N}$ latitude, $90^{\circ} 50^{\prime} \mathrm{E}$ longitude and at an altitude of 18 $\mathrm{m}$. The area falls under High Barind Tract agro-ecological zone (AEZ-26) having non-calcareous dark grey floodplain soil. The land was a medium high with moderate drainage facilities. The soil was silt loam having $\mathrm{pH}$ value of 6.5 . The particle density and bulk density values of soil were 2.60 and $1.35 \mathrm{~g}$ $\mathrm{cc}^{-1}$, respectively. Soil contained $1.78 \%$ organic matter, $0.14 \%$ total $\mathrm{N}, 1.98 \mu \mathrm{g}^{-1}$ available $\mathrm{P}, 0.10 \mathrm{meq}$ $100 \mathrm{~g}^{-1}$ exchangeable $\mathrm{K}$ and $4.56 \mu \mathrm{g} \mathrm{g}^{-1}$ available $\mathrm{S}$. The experimental area falls under the sub-tropical climate characterized by its heavy rainfall during Kharif season (April to September) and scanty rainfall during Rabi season (October to March).

\section{Experimental Treatments and Design}

The study included six combinations of three organic manures viz., (i) Trichocompost (TC) @ $3 \mathrm{t} \mathrm{ha}^{-1}$ $\left(\mathrm{T}_{1}\right)$; (ii) Vermicompost (VC) @ $3 \mathrm{t} \mathrm{ha}^{-1}\left(\mathrm{~T}_{2}\right)$; (iii) Mustard oil cake (MOC) @ $0.5 \mathrm{t} \mathrm{ha}^{-1}$ ( $\mathrm{T}_{3}$ ); (iv) =Trichocompost + mustard oil cake @ $0.5 \mathrm{t} \mathrm{ha}^{-1}\left(\mathrm{~T}_{4}\right)$; (v) Vermicompost + mustard oil cake @ $0.5 \mathrm{t} \mathrm{ha}^{-1}$ $\left(\mathrm{T}_{5}\right)$ and (vi) Control (no organic matter applied, $\mathrm{T}_{0}$ ) in a randomized complete block design (RCBD) with three replications. The size of each unit plot was $3 \mathrm{~m} \times 2.5 \mathrm{~m}$.

\section{Crop management}

The experiment was done under T. aman rice - mustard - DDS boro cropping pattern. Twenty five days old seedling of BRRI dhan57 was transplanted in well puddled land at $25 \mathrm{~cm} \times 15 \mathrm{~cm}$ spacing 
with three seedling hill ${ }^{-1}$ on 12 July 2017 . The crop was cultivated with recommended agronomic management practices as and when needed. The aman rice was harvested on 5 November 2017. Then mustard var. BARI Sharisha14 was sown on 27 November and harvested on 20 February 2018. After harvest of mustard, rice var. BRRI dhan28 was grown following the standard practices for dry direct

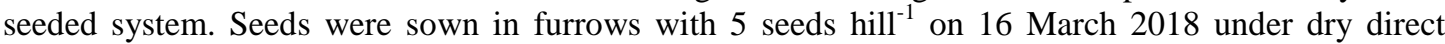
seeded system. The land was fertilized with urea, triple super phosphate, muriate of potash and gypsum at the rate of $375 \mathrm{~kg}, 60 \mathrm{~kg}, 92 \mathrm{~kg}$ and $70 \mathrm{~kg} \mathrm{ha}^{-1}$, respectively. The whole amount of triple super phosphate, muriate of potash and gypsum was applied at the time of final land preparation. Urea was applied in three equal splits at 21,42 and 63 days after sowing (DAS). Pre-emergence herbicide

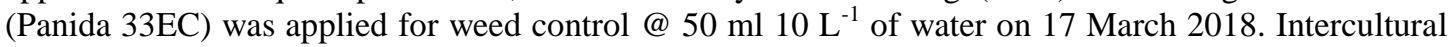
operations were done for maintaining the normal growth and development of the crop. Weeding was done twice by hand pulling at 21 and 41DAS. Irrigation was provided only to maintain the field at moist soil condition for successful crop growth and development. During the whole crop period, only four irrigations were given at 22, 43, 65 and 73 DAS. The crop was infested by Thrips which was

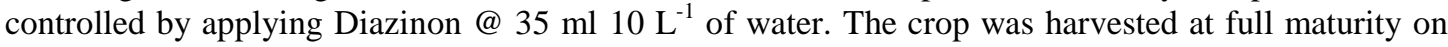
23 June 2018 from central $1.8 \mathrm{~m} \times 1.5 \mathrm{~m}$ area of each plot for recording yields of grain and straw. Grains and straw were sun dried and cleaned. Grain yields was adjusted to $14 \%$ moisture and converted to ton per hectare.

\section{Data recording}

Data on various plant characters like plant height, tiller production and yield contributing characters were recorded from randomly collected five hills plot ${ }^{-1}$ before plot harvest. After harvest of boro rice, soil sample was collected from 0 to $15 \mathrm{~cm}$ depth from the experimental field by iron core to record soil related data- soil $\mathrm{pH}$, bulk density, organic matter content $(\%)$, field capacity (\%), phosphorus and potassium content. After processing the soil was taken to the Humboldt Soil Lab of the Department of Soil Science, BAU. Soil pH was determined by Glass Electrode pH meter. The soil phosphorus was determined by Olsen method (Horta and Torrent, 2007). Soil organic matter content was determined by Wet oxidation method. For determining field capacity (\%) collected soils with cores were soaked with water for about 48 hours. After that soil was allowed to air dry about 72 hours and weighted. The field capacity $(\%)$ was determined using the following formulae.

Field capacity $(\%)=\frac{\text { Soil weight after } 72 \text { hour-oven dry soil weight }}{\text { Oven dry soil weight }} \times 100$

\section{Statistical Analysis}

The collected data were compiled and tabulated in proper form and were subjected to statistical analysis with the help of a computer package programme Statistix 10 and mean differences were adjudged by Duncan's Multiple Range Test.

\section{Results and Discussion}

\section{Crop yield and yield Parameters}

Organic amendment had significant effect on grain and straw yields, number of effective and noneffective tillers hill ${ }^{-1}$ but insignificant on plant height, number of total tillers hill ${ }^{-1}$, panicle length, number of grains panicle ${ }^{-1}$, number of sterile spikelets panicle ${ }^{-1}$ and 1000 -grain weight. Data presented in Table 1 revealed that the maximum plant height $(107.21 \mathrm{~cm})$ was observed in control treatment $\left(\mathrm{T}_{0}\right)$ and the shortest $(104.58 \mathrm{~cm})$ in TC + MOC @ $0.5 \mathrm{tha}^{-1}$ treatment $\left(\mathrm{T}_{4}\right)$. The highest number of effective tillers hill ${ }^{-1}$ (15.33) and non-effective tillers (3.67) was obtained with the treatment MOC @ 0.5ton ha ${ }^{-1}$ (T3). The lowest number of effective tillers hill ${ }^{-1}$ (12.33) and non-effective tillers was found in the 
control treatment (Table 1). The highest number of grains plant $^{-1}$ (85.33) was obtained from VC @ 3 ton $\mathrm{ha}^{-1}\left(\mathrm{~T}_{2}\right)$, and the lowest one (68.300) was observed with control. The highest number of sterile spikelet (26.66) was obtained from TC + MOC (T4), while the lowest (23.00) in control (Table 2). Numerically, the highest 1000 -grain weight $(20.75 \mathrm{~g})$ was obtained from $\mathrm{VC}+\mathrm{MOC}\left(\mathrm{T}_{5}\right)$ and the lowest weight (19.15 g) was obtained from $\mathrm{MOC}\left(\mathrm{T}_{3}\right)$.

Table 1. Effect of organic amendment on plant height and tiller production of dry direct seeded boro rice Var. BRRI dhan 28

\begin{tabular}{|c|c|c|c|c|c|}
\hline Treatments & $\begin{array}{l}\text { Plant height } \\
\text { (cm) }\end{array}$ & $\begin{array}{l}\text { Total tillers } \\
\text { hill }^{-1} \text { (no.) }\end{array}$ & $\begin{array}{c}\text { Effective tillers } \\
\text { hill }^{-1} \text { (no.) }\end{array}$ & $\begin{array}{c}\text { Non effective } \\
\text { tillers hill }^{-1} \text { (no.) }\end{array}$ & $\begin{array}{l}\text { Panicle } \\
\text { length } \\
\text { (cm) }\end{array}$ \\
\hline $\mathrm{T}_{0}$ & 107.15 & 12.67 & $12.33 \mathrm{~b}$ & $2.33 b$ & 23.33 \\
\hline $\mathrm{T}_{1}$ & 105.00 & 14.67 & $13.33 \mathrm{ab}$ & $2.33 b$ & 24.03 \\
\hline $\mathrm{T}_{2}$ & 105.83 & 15.67 & $13.00 \mathrm{ab}$ & $2.67 \mathrm{ab}$ & 23.03 \\
\hline $\mathrm{T}_{3}$ & 105.67 & 16.67 & $15.33 \mathrm{a}$ & $3.67 \mathrm{a}$ & 23.70 \\
\hline $\mathrm{T}_{4}$ & 104.58 & 16.67 & $15.00 \mathrm{ab}$ & $3.00 \mathrm{ab}$ & 27.73 \\
\hline $\mathrm{T}_{5}$ & 106.17 & 14.67 & $14.00 \mathrm{ab}$ & $2.67 \mathrm{ab}$ & 23.70 \\
\hline $\operatorname{LSD}(0.05)$ & NS & NS & 2.92 & 1.23 & NS \\
\hline $\mathrm{CV}(\%)$ & 1.63 & 12.10 & 7.47 & 15.65 & 3.81 \\
\hline
\end{tabular}

In a column, figures with same letter(s) or without letter do not differ significantly

$\mathrm{T}_{0}=$ Control (No organic matter used), $\mathrm{T}_{1}=$ Trico-compost (TC) @ $3 \mathrm{tha}^{-1}$ used, $\mathrm{T}_{2}=$ Vermicompost @ ha ${ }^{-1}, \mathrm{~T}_{3}=$ Mustard oil cake @ $0.5 \mathrm{ha}^{-1}, \mathrm{~T}_{4}=$ Trichocompost + Mustard oil cake , $\mathrm{T}_{5}=$ Vermicompost + Mustard oil cake

Table 2. Effect of organic amendment on yield and related attributes of dry direct seeded boro rice Var. BRRIdhan28

\begin{tabular}{|c|c|c|c|c|c|}
\hline Treatments & $\begin{array}{c}\text { Grains } \\
\text { panicle }^{-1}(\text { no. })\end{array}$ & $\begin{array}{l}\text { Sterile spikelet } \\
\text { panicle }^{-1} \text { (no.) }\end{array}$ & $\begin{array}{c}\text { Weight of } \\
\text { 1000-grain }(g)\end{array}$ & $\begin{array}{c}\text { Grain yield } \\
\text { ha }^{-1} \text { (ton) }\end{array}$ & $\begin{array}{c}\text { Straw yield } \\
\text { ha }^{-1} \text { (ton) }\end{array}$ \\
\hline $\mathrm{T}_{0}$ & 68.30 & 23.00 & 20.19 & $4.25 \mathrm{~b}$ & $4.68 \mathrm{~b}$ \\
\hline $\mathrm{T}_{1}$ & 72.77 & 26.00 & 19.89 & $5.95 \mathrm{a}$ & $5.41 \mathrm{a}$ \\
\hline $\mathrm{T}_{2}$ & 85.33 & 26.33 & 20.08 & $5.57 \mathrm{a}$ & $5.07 \mathrm{ab}$ \\
\hline $\mathrm{T}_{3}$ & 77.80 & 24.33 & 19.15 & $5.25 \mathrm{ab}$ & $5.37 \mathrm{a}$ \\
\hline $\mathrm{T}_{4}$ & 73.13 & 26.67 & 20.06 & $5.61 \mathrm{a}$ & $5.38 \mathrm{a}$ \\
\hline $\mathrm{T}_{5}$ & 73.07 & 25.00 & 20.75 & $5.48 \mathrm{ab}$ & $5.46 \mathrm{a}$ \\
\hline CV (\%) & 8.94 & 11.93 & 4.69 & 8.33 & 4.41 \\
\hline $\operatorname{LSD}\left({ }_{0.05)}\right.$ & NS & NS & NS & 1.26 & 0.65 \\
\hline
\end{tabular}

In a column, figures with same letter(s) or without letter do not differ significantly, whereas figures with dissimilar letter(s) differ significantly

$\mathrm{T}_{0}=$ Control (No organic matter used), $\mathrm{T}_{1}=$ Trico-compost $(\mathrm{TC}) @ 3 \mathrm{tha}^{-1}$ used, $\mathrm{T}_{2}=$ Vermicompost $@$ ha $^{-1}, \mathrm{~T}_{3}=$ Mustard oil cake @ $0.5 \mathrm{ha}^{-1}, \mathrm{~T}_{4}=$ Trichocompost + Mustard oil cake, $\mathrm{T}_{5}=$ Vermicompost+Mustard oil cake

The maximum grain yield $\left(5.95 \mathrm{t} \mathrm{ha}^{-1}\right)$ was observed in the treatment TC @ 5 ton ha ${ }^{-1}\left(\mathrm{~T}_{1}\right)$, while the lowest one $\left(4.25 \mathrm{t} \mathrm{ha}^{-1}\right)$ in control $\left(\mathrm{T}_{0}\right)$. The result revealed that yield improvement was obtained with the organic amendment with Tricho-compost alone or in combination with mustard oil cake. The grain yield obtained with $\mathrm{TC}$ was similar with those of $\mathrm{T}_{2}$ and $\mathrm{T}_{4}$. However, the highest straw yield (5.66tha ${ }^{1}$ ) was observed in the treatment $\mathrm{VC}+\operatorname{MOC}\left(\mathrm{T}_{5}\right)$, while the lowest one $\left(4.68 \mathrm{t} \mathrm{ha}^{-1}\right)$ in control treatment. Thus, the result clearly showed that the yield improvement of direct seeded boro rice was possible through organic amendment with trichocompost or vermicompost @ $3 \mathrm{t} \mathrm{ha}^{-1}$. Benbi et al. (1998) also found that farm yard manure in combination with NPK chemical fertilizers resulted in higher soil organic carbon concentration and enhanced crop growth along with higher root biomass production.

Organic matter amendment is effective in increasing rice yield. Organic amendment with compost along with application of chemical fertilizers increased the biomass and grain yields of crops (Saleque et al., 2004, Sarwar et al., 2007). Several studies also reported that long - term organic amendment increased rice yield in rice - wheat system (Shamsuhddin and Fauziah, 2010; Mitran and Mani, 2017). 
Mitran and Mani (2017) reported that the long-term application of inorganic fertilizer in conjunction with FYM, PS, and GM had a significant effect on maintaining positive yield trend in case of rice under such rice - wheat system over control.

\section{Soil physical and chemical properties}

Organic amendment did not have significant effect on $\mathrm{pH}$, organic matter content, bulk density, field capacity, phosphorus and potassium content of soil of the experimental field after harvest of the dry direct seeded rice (Table 3). However, the lowest $\mathrm{pH}$ of soil (5.8) was found in control $\left(\mathrm{T}_{0}\right)$ and the highest (6.02) was observed in the treatment Tricho-compost $\left(\mathrm{T}_{1}\right) @ 3 \mathrm{t} \mathrm{ha}^{-1}$. The highest OM of soil (1.08) was found with mustard oil cake $\left(\mathrm{T}_{3}\right) @ 0.3 \mathrm{t} \mathrm{ha}^{-1}$ and the lowest $(0.84)$ was with Vermicompost treatment @ $3 \mathrm{t} \mathrm{ha}^{-1}\left(\mathrm{~T}_{2}\right)$. The highest BD of soil (1.43) was determined in the treatment Trichocompost @ $3 \mathrm{tha}^{-1}\left(\mathrm{~T}_{1}\right)$ and the lowest (1.32) was in Vermicompost + MOC @ $0.5 \mathrm{t} \mathrm{ha}^{-1}\left(\mathrm{~T}_{5}\right)$. However, the highest FC of soil (33.83) was found in Vermicompost + mustard oil cake @ 0.5 tha $^{-1}\left(\mathrm{~T}_{5}\right)$ treatment and the lowest (31.20) in Trichocompost @ $3 \mathrm{t} \mathrm{ha}^{-1}$ treatment $\left(\mathrm{T}_{1}\right)$. Phosphorus was the highest (24.9) in the treatment Trichocompost @ $3 \mathrm{tha}^{-1}\left(\mathrm{~T}_{1}\right)$ and lowest $(16.23)$ in Vermicompost treatment @ $0.3 \mathrm{t}$ $\mathrm{ha}^{-1}\left(\mathrm{~T}_{2}\right)$. The treatment Vermi-compost @ $3 \mathrm{tha}^{-1}\left(\mathrm{~T}_{2}\right)$ had the highest $\mathrm{K}$ of soil $(0.17)$, while the lowest (0.15) in Vermicompost + MOC @ $0.5 \mathrm{t} \mathrm{ha}^{-1}$ treatment $\left(\mathrm{T}_{5}\right)$. It was noted that soil $\mathrm{pH}$ and soil organic matter were consistently higher in $\mathrm{T}_{4}$ and $\mathrm{T}_{5}$ than those in other treatments. On the other hand, soil bulk density, field capacity and soil phosphorus content were consistently higher in $T_{4}$ and $T_{3}$ than those in other treatments. However, soil potassium was consistently high in $T_{4}$ and $T_{1}$ than the other treatments. Earlier report indicated that integrated nutrient management through the combined use of inorganic and organic fertilizers increased crop yield and improved $\mathrm{N}$ and $\mathrm{K}$ use efficiency (Ryan et al., 2017). It was also disclosed that the efficiency of fertilizer $P$ use could possibly be increased by recycling of $\mathrm{P}$ from crop residues, and organic and mineral fertilizers (Hedge and Dwivedi, 1993). Integrated use of organic manures and fertilizers not only improved the efficiency of P (Vats et al., 2001) but also significantly increased the availability of P. Mitran and Mani (2017) observed that long - term organic amendment increased P content in rice soil. Organic amendment also improved water use efficiency (WUE) of crop plants by improving soil water holding capacity as reported by Shehzadi et al. (2017)). A high WUE is a good indicator of a crop to cope with soil water deficit and provides a greater opportunity for increasing grain yield (Zhou et al., 2017).

Table 3. Effect of organic amendment on soil physical and chemical characteristics after growing direct seeded boro rice in a rice-mustard-direct seeded rice system

\begin{tabular}{lcccccc}
\hline Treatments & $\mathbf{p H}$ & $\begin{array}{c}\text { Organic } \\
\text { matter } \mathbf{\%})\end{array}$ & $\begin{array}{c}\text { Phosphorus }_{\mathbf{m e q 1 0 0 g}^{-1}} \\
\text { Potassium }_{\mathbf{m e q 1 0 0 g}^{-1}}\end{array}$ & $\begin{array}{c}\text { Bulk } \\
\text { density } \\
\left(\mathbf{g ~ c m}^{-3}\right)\end{array}$ & $\begin{array}{c}\text { Field } \\
\text { capacity } \\
(\%)\end{array}$ \\
\hline $\mathrm{T}_{0}$ & 5.8 & 1.04 & 22.39 & 0.16 & 1.42 & 32.58 \\
$\mathrm{~T}_{1}$ & 6.0 & 1.01 & 24.97 & 0.16 & 1.43 & 31.20 \\
$\mathrm{~T}_{2}$ & 6.1 & 0.84 & 16.23 & 0.17 & 1.33 & 31.98 \\
$\mathrm{~T}_{3}$ & 6.2 & 1.08 & 22.43 & 0.16 & 1.36 & 31.85 \\
$\mathrm{~T}_{4}$ & 6.3 & 1.06 & 17.66 & 0.16 & 1.35 & 31.54 \\
$\mathrm{~T}_{5}$ & 6.2 & 0.91 & 10.93 & 0.15 & 1.32 & 33.81 \\
\hline $\mathrm{CV}(\%)$ & 3.68 & 18.14 & 33.04 & 15.46 & 6.26 & 9.52 \\
$\mathrm{LSD}_{0.05}$ & $\mathrm{NS}$ & $\mathrm{NS}$ & $\mathrm{NS}$ & $\mathrm{NS}$ & $\mathrm{NS}$ & $\mathrm{NS}$ \\
\hline
\end{tabular}

In a column, figures with same letter(s) or without letter do not differ significantly, whereas figures with dissimilar letter(s) differ significantly; $\mathrm{ns}=$ non significance, $\left[\mathrm{T}_{0}=\right.$ Control (No organic matter used), $\mathrm{T}_{1}=$ Trico-compost (TC) @ $3 \mathrm{t}$ $\mathrm{ha}^{-1}$ used, $\mathrm{T}_{2}=$ Vermicompost@ ha ${ }^{-1}, \mathrm{~T}_{3}=$ Mustard oilcake@ $0.5 \mathrm{ha}^{-1}, \mathrm{~T}_{4}=$ Trichocompost + Mustard oil cake , $\mathrm{T}_{5}=$ Vermicompost+Mustard oil cake.] 


\section{Conclusion}

Organic amendment significantly influenced the yield performance of dry direct seeded boro rice and the highest grain yield was obtained with TC @ 0.3 tha $^{-1}\left(\mathrm{~T}_{1}\right)$. Thus, organic matter amendment along with recommended chemical fertilization applicaton is an important management option for obtaining the high grain yield of dry direct seeded boro rice in a rice based cropping system.

\section{Acknowledgement}

We are highly grateful to the Project Implementation Unit of Bangladesh Agricultural Research Council (BARC), Farmgate, Dhaka-1215 for funding under the Competitive Research Grant (CRG) sub-project \# 777 under NATP2.

\section{References}

AIS. 2020. Agricultural Diary, Agricultural Information Service, Khamar Bari, Dhaka-1215.

Basak, J.K., M.A. Ali, M.N. Islam and M.J.B. Alam. 2009. Assessment of the effect of climate change on boro rice production in Bangladesh using CERES-Rice model, Proceedings of the International Conference on Climate Change Impacts and Adaptation Strategies for Bangladesh, 18-20 February 2009. pp.103-113.

Benbi D.K., C.R. Biswas, S.S. Bawa and K. Kumar. 1998. Influence of farmyard manure, inorganic fertilizer and weed control practices on some soil physical properties in a long-term experiment. Soil Use Manage. 14: 52-54.

Hegde, D.M. and B.S. Dwivedi. 1993. Integrated nutrient management for dry land agriculture. Fert. News. 39(4): 19-26.

Horta, M.C. and J. Torrent. 2007. The Olsen P method as an agronomic and environmental test for predicting phosphate release from acid soils. Nutr. Cycl. Agroecosyst. 77: 283-292.

Minasny, B. and A.B. Mcbratney. 2018. Limited effect of organic matter on soil available water capacity. European J. Soil Sci. 69: 39-47.

Mitran, T. and P.K. Mani. 2017. Effect of organic amendments on rice yield trend, phosphorus use efficiency, uptake, and apparent balance in soil under long-term rice-wheat rotation. J. Plant Nutri. 40(9): 1312-1322.

Pandey, S. and L. Velasco. 2005. Trends in crop establishment methods in Asia and research issues. In: Rice is Life: Scientific Perspectives for the $21^{\text {st }}$ Century, Proceedings of the World Rice Research Conference, 4-7 November 2004, Tsukuba, Japan, pp.178-181.

Rahman, M.M. 2018. Dry Direct Seeded Boro Rice Based Cropping Patterns for Producing More with Less Water. Department of Agronomy, Bangladesh Agricultural University, Mymensingh. pp.1-28.

Rahman, M.M. 2019. Potential benefits of dry direct seeded rice culture: A review. Fund. and Appl. Agric. 4(2): $1-15$

Rahman, M.M., M.A. Uddin and M.M. Masood. 2012. Irrigation water saving, yield performance and costeffectiveness of different rice cultivation systems in boro season. Bangladesh Agron. J. 15(1): 99106.

Rahman, M.M. and M.M. Masood. 2014. Sustaining productivity in boro (winter) season using minimal water through dry direct seeding of rice. J. Crop Weed. 10(2): 24-30.

Rahman, M.M., M.M. Masood and M.A.R. Sarkar. 2020. Water management effects on irrigation cutback and yield performance of dry direct seeded boro rice. Asian Australas. J. Biosci. Biotechnol. 5(1): 6-14. 
Ryan, T., S. Pearl, B. Sanchez, B. Rodrigo, E. Badayos, S. Paterno and P.C. Sta. Cruz. 2017. Effect of organic amendments and microbial inoculant on nitrogen, phosphorus and potassium use efficiency of sugarcane under acid typic hapludand. J. Inter. Soc. Southeast Asian Agril. Sci. 23(2): 114124.

Saleque, M.A., M.J. Abedin, N.I. Bhuiyan, S.K. Zaman and G.M. Panaullah. 2004. Long-term effects of inorganic and organic fertilizer sources on lowland rice. Field Crop Res. 86: 53-65.

Sarwar, G., N. Hussain, H. Schmeisky and S. Muhammad. 2007. Use of compost an environment friendly technology for enhancing rice-wheat production in Pakistan. Pak. J. Bot. 39(5): 1553-1558.

Shamshuddin, J. and C. Fauziah. 2010. Alleviating acid soil infertility constraints using basalt, ground magnesium limestone and gypsum in a tropical environment. Malaysian. J. Soil Sci. 14: 1-13

Shehzadi, S., Z. Shah and W. Mohammad. 2017. Impact of organic amendments on soil carbon sequestration, water use efficiency and yield of irrigated wheat. Biotechnol. Agron. Soc. Environ. 21(1): 36-49.

Vats, M.R., D.K. Sehgal, and D.K. Meheta. 2001. Integrated effect of organic and inorganic manuring on yield sustainability in long-term fertilizer experiments. Indian J. Agril. Res. 35: 19-24.

Zhou, Q., C.X. Ju, Z.Q. Wang, H. Zhang, L.J. Liu, J.C. Yang and J.H. Zhang. 2017. Grain yield and water use efficiency of super rice under soil water deficit and alternate wetting and drying irrigation. J. Integra. Agric. 16: 1028-1043. 